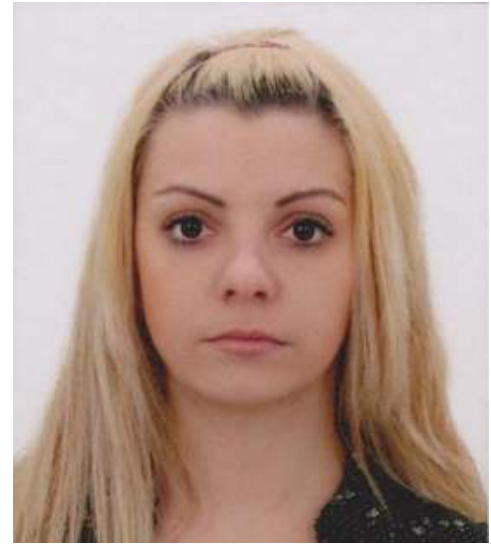

Анна Струк,

кандидат педагогічних наук, викладач кафедри

фрахових методик і технологій початкової освіти, ДВНЗ «Прикарпатський національний університет імені Василя Стефраника» (м. Івано-Франківськ, Україна)

\author{
Anna Struk, \\ $\mathrm{PhD}$ in Education, Lecturer, \\ Department of Professional Methods and Technologies \\ of Primary Education, \\ Vasyl Stefanyk Precarpathian National University \\ (Ivano-Frankivsk, Ukraine) \\ anna.zharovska@pu.if.ua \\ ORCID ID 000-0001-6442-8098
}

\title{
ЛЕКСИКО-НАРОДОЗНАВЧА КОМПЕТЕНТНІСТЬ ЯК СКЛАДОВА ПРОФЕСІЙНОГО МОВЛЕННЯ МАЙБУТНЬОГО ВЧИТЕЛЯ ПОЧАТКОВОЇШКОЛИ
}

Анотація. В статті висвітлюються особливості лексико-народознавчої компетентності як складової професійного мовлення майбутнього вчителя початкової школи.

Метою статті є використання професійного мовлення задля формування лексико-народознавчої компетентності майбутнього вчителя початкової школи.

Запропоновано використовувати певні принципи навчання і методи для кращого засвоєння лексико-народознавчої компетентності як складової професійного мовлення майбутніх вчителів початкової школи.

Обґрунтовано сутність основних компетенцій майбутнього вчителя початкової школи, серед яких особливу увагу приділено лексико-народознавчій.

Проблема реалізації лексико-народознавчої компетентності як складова професійного мовлення майбутнього вчителя початкової школи повинна реалізовуватися в процесі навчання студентів вищої школи. Це зумовлено реформуванням вищої ланки освіти на нових концептуальних засадах у зв'язку з новими цілями, поставленими суспільством на сучасному етапі його розвитку.

Професійно-мовленнєва компетентність майбутніх вчителів початкової школи - це багатокомпонентне утворення, складниками якої є лінгвістична, та народознавча компетентності.

Народознавча компетентність має складну структуру, тому слід визначити ії̈ процес формування. Цей процес розглядається як отримання індивідом об'єктивних знань та уявлень щодо своєї етнічної культури, історії рідного краю, звичаїв, традицій своєї нації.

Проблема лексико-народознавчої компетентності як складова професійного мовлення майбутнього вчителя початкової школи $є$ відкритою на сьогоднішній день. Вона передбачає вивчення сутності поняття професійної компетентності вчителя і його особливостей. Аналіз проблеми розвитку професійної компетентності вчителя у вітчизняних педагогічних школах з позиції лексико-народознавчих підходів свідчить про появу нових досліджень, пов'язаних з розробкою науково-педагогічних засад професійної підготовки фахівців.

Ключові слова: лексика, народознавча лексика, компетенція, лексико-народознавча компетентність, професійне мовлення, майбутні вчителі, початкова школа.

\section{LEXICAL AND ETHNOLOGICAL COMPETENCE AS A COMPONENT OF PROFESSIONAL SPEECH OF THE FUTURE PRIMARY SCHOOL TEACHER}

Abstract. In the article, the peculiarities of lexical and ethnological competence as a component of professional speech of the future primary school teacher are highlighted.

The purpose of the article is to use professional speech for forming lexical and ethnological competence of the future primary school teacher.

The use of certain principles of teaching and methods for a better acquisition of lexical and ethnological competence as a component of professional speech of the future primary school teachers is suggested.

The essence of the basic competences of the future teacher of primary school, among which special attention is paid to lexical and ethnological studies, is substantiated,

The problem of the implementation of lexical and ethnological competence as a component of professional speech of the future primary school teacher should be implemented in the process of training students of higher education. This is due to 
the reform of the highest level of education on the new conceptual basis in connection with the new goals set by the society at the present stage of its development.

Professional-speaking competence of the future primary school teachers is a multi-component formation that includes linguistic and ethnographic competence.

The ethnological competence has a complex structure, so its formation process should be determined. This process is regarded as obtaining by the individual of objective knowledge and ideas about his ethnic culture, history of his native land, customs and traditions of his nation.

The problem of lexical and ethnological competence as a component of professional speech of the future primary school teacher is open today. It involves the study of the essence of the concept of professional competence of the teacher and its features. The analysis of the problem of the development of teacher's professional competence in domestic pedagogical schools from the point of view of lexical and ethnological approaches suggests the emergence of new research related to the development of scientific and pedagogical principles of professional training of specialists.

Keywords: vocabulary, ethnologic vocabulary, competence, vocabulary competence, professional speech, future teachers, elementary school.

\section{ВСТУП}

Постановка проблеми. Проблема професійної підготовки вчителя висвітлюється в багатьох працях (К. Авраменко, В. Бондар, А. Кушнір, О. Пєхота, Л. Сущенко, Л. Хомич та ін.). Їх аналіз дозволяє стверджувати, що поняття «професійна підготовка» в широкому розумінні дослідники переважно розуміють як невід'ємну складову системи вищої педагогічної освіти. Так, в «Українському педагогічному словнику» С. Гончаренка термін «професійна педагогічна підготовка» тлумачиться як «підготовка педагогічних і науково-педагогічних кадрів для навчальних закладів усіх типів» [3, с. 326.].

Сучасний професійно зорієнтований підхід передбачає збагачення і уточнення системи знань 3 українського народознавства, практичне втілення набутих знань і вмінь, сформованих навичок лексико-народознавчої роботи в активній професійно-мовленнєвій діяльності та усвідомлення майбутніми вчителями місця і значення лексико- народознавчої роботи в навчально-виховній системі початкової школи.

3 метою формування професійно значущих комунікативних умінь і навичок майбутніх фрахівців науковці вважають за доцільне здійснювати професійно зорієнтоване навчання вчителя початкових класів. Одним із продуктивних напрямів професійної орієнтації майбутнього фрахівця $€$ формування професійно-лінгвістичної компетентності збагачення усного й писемного мовлення народознавчою лексикою, формування вмінь сприймати й розуміти народознавчі терміни, володіти лексичним і фразеологічним багатством мови. Кінцевою метою такого підходу $€$ підготовка фахівців відповідно до потреб сучасного світового ринку праці. Тому важливим, на наш погляд, $€$ використання компетентнісного підходу в процесі професійної підготовки фахівців початкової освіти.

МЕТА I ЗАВДАННЯ ДОСЛІДЖЕННЯ - теоретичне обґрунтування принципів навчання лексико-народознавчої компетентності як складової професійного мовлення майбутнього вчителя початкових класів.

МЕтодИ ДослІДЖЕНня: аналіз, систематизація та узагальнення наукової літератури з питань лексиконародознавчої компетентності майбутнього вчителя початкової школи.

\section{РЕЗУЛЬТАТИ ДОСЛІДЖЕННЯ}

Проблема компетентнісного підходу до освіти широко досліджується науковцями (Н. Бібік, Н. Денисова, В. Краєвський, О. Локшина, І. Ніконенко, О. Овчарук, О. Пометун, О. Савченко, А. Хуторський та ін.), які підкреслюють його інтернаціональний характер. На їх думку, набуття молоддю знань, умінь і навичок, спрямоване на вдосконалення їхньої компетентності, сприяє культурному розвитку особистості, формуванню в неї здатності оперативно реагувати на запити часу.

Компетентнісний аспект навчання мови термінологічно пов'язаний з поняттями «компетенція», «компетентність», «мовна компетенція», «мовленнєва компетенція», «комунікативна компетенція».

У науковий обіг поняття «компетентність», «компетенція», «компетентнісний підхід», увійшли 3 професійної сфери, тому більшість європейських дослідників розглядають «компетентність» як оцінну категорію, що характеризує людину як суб'єкта професійної діяльності, її здатність успішно виконувати свої повноваження [7]. Термін «компетенція» сьогодні широко використовується там, де йдеться про навчання та виховання. За словами В. Краєвського та А. Хуторського, компетенція - це коло питань, щодо яких людина добре обізнана, пізнала їх на основі власного досвіду, а компетентність у визначеній галузі - це поєднання відповідних знань і здібностей, що дозволяють обґрунтовано судити про цю сферу й ефективно діяти в ній [5].

Досліджуючи поняття компетентність, В. Кальней, Ю. Шаповал доходять висновку, що компетенція - це загальна здібність, що ґрунтується на знаннях, досвіді, цінностях, схильностях, які надбані завдяки навчанню [11]. Компетенція не може зводитись до знань, навичок, бути компетентним не означає бути вченим або освіченим.

За словами В. Кальней та Ю. Шаповал, про компетенцію йдеться тоді, коли вона виявляється у будь-якій ситуації; невиявлена компетенція є тільки потенційною, і вона вже не є компетенцією, а тільки прихованою можливістю [11]. Найскладніша проблема в тому, щоб визначити ті знання, які б забезпечили фрормування необхідної компетенції.

З культурно-історичних позицій компетентність у смисловому значенні охоплює три аспекти: знання, вміння, навички. Крім того, компетентність - це гармонійне співвідношення «хочу», «можу» і «треба». Саме компетентність виконує ряд функцій: уміння вибирати відповідну інфрормацію для виконання дій задля досягнення необхідної 
мети або для побудови нової дії. Натомість Т. Попова визначає компетентність як загальну здатність жити в суспільстві, що ґрунтується на певних знаннях, досвіді, цінностях, здібностях, набутих у процесі навчання [8].

С. Ожегов визначає компетентну людину як освічену, авторитетну в певній галузі. Подібно розуміють це поняття Дж. Равен та А. Бодальов. Згідно з першим, компетентність - «це специфічна здібність, необхідна для ефективного виконання конкретної дії в конкретній предметній галузі, це володіння вузькоспеціальними знаннями, особливого роду предметними навичками, способами мислення, а також розуміння відповідальності за свої дії» [10]. А. Бодальов уважає, що компетентність - це «специфічна здібність, яка дозволяє ефективно вирішувати типові проблеми і завдання, що виникають у реальних ситуаціях повсякденного життя». Це «вміння вирішувати окреслене коло завдань у професійних видах діяльності» [2].

Р. Стернберг [9], аналізуючи природу компетентності, підкреслює, що психологи досліджують і визначають сутність цього явища з двох позицій. У межах першої вона розглядається як наслідок розвитку певних розумових процесів, а саме: планування, відслідковування, оцінки рішення проблеми, прийняття рішення, одержання й обробка інформації тощо. За другою позицією, компетентність - це наслідок накопичення людиною бази знань і досвіду різних способів її організації та реорганізації. Цікаво, що, розглядаючи сутність компетентності 3 другої, зазначеної вище позиції, Р. Стернберг наголошує на тому, що створювана і певним чином організована база знань, проблемні схеми, які виникають разом із нею, складають фундамент для всіх різноманітних видів компетентності [9]. Тобто залежно від того, які знання утворюють базу щодо розуміння певного предмета (певної сфери дійсності, певної галузі науки) визначається сфера компетентності спеціаліста. Кількісний склад цієї бази і спосіб організації знань, що входять до неї, визначають межі і характер розв'язання тих проблем, які можуть бути вирішеними за допомогою певної бази знань.

Отже, компетенцію потрібно розуміти як реальну вимогу до засвоєння учнями сукупності знань, способів діяльності, досвіду, ставлення з певної галузі знань, якостей особистості, яка діє в соціумі, а компетентність як реально сформовані особистісні якості учня та досвід діяльності.

На нашу думку, «компетентність» - це комплексна характеристика особистості, яка включає суму знань, навичок та відношень, що дають змогу ефективно здійснювати певну діяльність. На кожному віковому етапі компетентність має орієнтовні показники розвитку особистості.

Компетентнісний підхід до навчання мови включає низку понять, на яких групується мовленнєва діяльність учнів початкової школи й відбувається формування їхньої комунікативної компетенції. Це текст (контекст), мовленнєва діяльність та ії види, сфера і ситуації спілкування та ін. Більшість цих понять функціонує в професійному мовленні вчителів-словесників, засвоюється учнями й забезпечує формування їх комунікативної компетентності, а далі розвивається у вищій школі.

Формування комунікативної компетенції справді $€$ нагальною проблемою сучасної мовної освіти, а компетентнісний підхід до навчання української мови є одним із актуальних.

Народознавчий підхід визначається нами як один із пріоритетних у перебудові освіти в Україні. Суть його зводиться до того, що саме рідна мова $€$ засобом пізнання самого себе як представника української нації, свого народу, його історії, культури тощо.

Опанування українською мовою як найважливішим засобом національного виховання забезпечує не тільки комфрортне існування молодої людини в суспільстві, але й дозволяє виробити систему національно зумовлених уявлень, пізнавати національний характер, визначити мовний тип особистості.

У «Концепції навчання державної мови в школах України» народознавчий компонент розглядається як один зі складників навчання рідної мови, який повинен бути інтегрованим за своїм змістом і містити найважливіші відомості з народознавства, пов'язані з історією, культурою, звичаями, побутом українського народу [6]. Зазначене викликає необхідність виокремити шар народознавчої лексики, яким повинен володіти фахівець певної педагогічної галузі.

Дослідження народознавчої лексики було започатковано у 80-х pp. XX століття. Учені доводять, що з допомогою народознавчої лексики людина залучається до історії свого народу, до його духовності, пізнає генетичний код своєї нації.

У педагогічній літературі є багато визначень поняття «народознавство».

«Народознавство - це сукупність знань сучасних наук про народ, його багатогранне життя, історично зумовлені сорери творчої діяльності.

Народознавство - це галузь емпіричних педагогічних знань і досвіду народу, виражена в домінуючих поглядах на мету і завдання виховання у сукупності народних засобів, умінь і навичок виховання та навчання.

Народознавство - це система знань про мову, літературу, історію, географію, психологію, демографрію народу, яка запобігає історичному безпам'ятству і сприяє фрормуванню у дітей народного світогляду та прилученню до світової культури через народ» [1, с. 5).

В «Енциклопедії українознавства» подано таке визначення: «Народознавство - система знань про конкретний народ, особливості його побуту і трудової діяльності, національний характер, психологію, світогляд, історикокультурний досвід, а також про родовід, спосіб життя і виховання в сім'ях, про рідний край і все, пов'язане 3 ним» $[4$, с. 276.]. 
Принцип народності у поєднанні з вивченням мовних явищ обстоювали такі видатні вчені, як К. Ушинський, М. Стельмахович, а започаткований він ще у XIX столітті С. Русовою. На думку М. Стельмаховича, в основу методики вивчення рідної мови має бути закладений принцип народності, завдяки якому відбувається прищеплення студентами любові до рідного слова через вивчення всіх жанрів українського фольклору, що сприяють національному вихованню.

А. Богуш виділяє принцип історизму як центральний і такий, що може висвітлювати народознавство об'єктивно і вичерпно. На думку вченої, ігнорування принципу історизму призводить до відриву майбутнього від минулого, до порушення історичного ланцюжка, до руйнування закономірної єдності поколінь, яка закодована в історії кожного народу, кожної нації. Отже, народознавство - це історична галузь науки, яка висвітлює переважно традиційно-побутову культуру - звичаї, символи, традиції, фольклор, ремесла у різні історичні періоди розвитку держави та нації [1, с. 5].

Таким чином, проаналізувавши думки вчених, ми виділили такі принципи навчання, які повинні сприяти фрормуванню лексико-народознавчої компетентності майбутнього вчителя початкових класів: принцип науковості, принцип активності й самостійності студентів, принцип єдності теорії і практики, принцип послідовності, принцип міцності засвоєння знань.

Принцип науковості передбачає аналіз, систематизацію та узагальнення науково-методичної літератури, розробку спецкурсів задля формування лексико-народознавчих компетентності.

Принцип активності й самостійності студентів реалізується шляхом занурення студентів в активну навчальномовленнєву діяльність лексико-народознавчої спрямованості.

Принцип єдності теорії і практики полягає в тому, що оскільки навчання студентів народознавчої лексики зумовлене життєвою необхідністю пізнати український народ, його культуру, ментальність, спосіб життя, робота над засвоєнням студентами таких слів має сприяти використанню їх у повсякденному мовленні.

Відповідно до принципу послідовності підготовка студентів повинна організовувалась за етапами: оволодіння теоретичними знаннями (лекції), набуття умінь та навичок (семінарські заняття) та застосування набутих умінь і навичок (творча робота).

Принцип міцності засвоювання знань займає одне з провідних місць у підготовці студентів до формування лексико-народознавчої компетентності. Він передбачає такі види роботи, як повторення, запам'ятовування, використання, постійна систематизація, поглиблення знань навчального матеріалу та вдосконалення практичних навичок і вмінь, що дає можливість сформувати лексико-народознавчу компетентність як складову професійного мовлення майбутнього вчителя початкових класів.

Для кращого розуміння і використання цих принципів пропонується використовувати такі групи методів: словесні, наочні, практичні.

Серед словесних методів навчання ми пропонуємо використовувати: метод розповіді, який передбачає усний живий, образний, емоційний і послідовний виклад переважно фрактичного матеріалу в розповідній фрормі. Цей метод можна використовувати під час проведення лекцій, семінарських занять, різноманітних зустрічей, виховних заходів, інсценізованого уроку.

Лекція використовується для розгорнутого теоретичного повідомлення, наукового аналізу та обґрунтування складних і об'ємних наукових проблем.

Бесіда - метод словесного обговорення матеріалу, що вивчається, - найпоширеніша в навчанні. Під час проведення семінарських занять можна використовувати такі види бесіди: вступна, бесіда-повідомлення, бесіда-повторення, контрольна, евристична.

Дискусія - дієвий метод обговорення питання, що вивчається. Вона передбачає колективне обговорення якоїсь спірної проблеми, під час якого пізнається істина.

3-поміж наочних методів навчання ми пропонуємо використовувати метод показу. Показ - це навчальний метод, що являє собою сукупність прийомів, дій і засобів, за допомогою яких у студентів створюється наочний образ предмета, котрий вивчається, формується конкретне уявлення про нього.

3-поміж практичних методів навчання пропонуємо використовувати вправи - метод, який використовується з метою формування, закріплення та вдосконалення практичних навичок і вмінь студентів. На кожному семінарському занятті можна використовувати вправи для фрормування та вдосконалення умінь і навичок, необхідних для роботи над народознавчою лексикою.

Використання перечислених принципів і методів навчання студентів буде сприяти формуванню їхньої лексико-народознавчої компетентності.

\section{ВИСНОВКИ ТА ПЕРСПЕКТИВИ ПОДАЛЬШИХ ДОСЛІДЖЕНЬ}

Головним завданням учителя початкової школи $€$ не лише прищепити інтерес до вивчення рідної мови як засобу спілкування, а й продемонструвати всю велич і красу рідного слова. Вивчення рідної мови варто починати з «повернення генетичної пам'яті народу», тому що через засвоєння рідної мови дитина пізнає світ, формується як особистість, як громадянин України. Втіленню означених завдань сприяє реалізація українознавчого компонента. Саме це відкриває шлях до пізнання самого себе як представника української нації, свого народу, його історії, культури. 


\section{СПИСОК ВИКОРИСТАНИХ ДЖЕРЕЛ}

[1] Богуш А. М. Лисенко Н. В. Українське народознавство в дошкільному закладі. Практикум : навч. посіб. К. : Вища шк., 2003.206 с.

[2] Бодалев А. Психология новой эры : компетентности или беспомощность . URL: http://psy.l September.Ru/2001/47/45.htm.

[3] Гончаренко С. У. Український педагогічний словник. К. : Либідь, 1997. 376 с.

[4] Енциклопедія українознавства для школярів і студентів / авт.-уклад. В. В. Оліфіренко, Т. В. Оліфріренко, Л. В. Оліфріренко. Д. : Сталкер, 1999. 496 с.

[5] Краевський В. Предметное и общепредметное в образовательных стандартах. Педагогіка. 2003. № 3. С. 3-10.

[6] Концепція мовної освіти 12-річної школи. Дивослово. 2002. № 8. С. 58-62.

[7] Новий тлумачний словник української мови : у 4 т. / уклад. В. Яременко, О. П. Сліпушко. К. : Аконіт, 1999. Т. ІІ. С. 305.

[8] Попова Т. Формування соціальної компетентності учнів. Педагогічна скарбниця Донеччини. 2004. № 2 (20). С. $42-43$.

[9] Практический интеллект / под. общ. ред. Р. Стенберга. СПб. : Питер, 2002. 272 с.

[10] Равен Дж. Педагогическое тестирование: Проблемы, заблуждения, перспективы / Дж. Равен ; пер. с англ. М. : КогитоЦентр,1999. 144 с.

[11] Шаповал Ю. Педагогічні умови формування готовності майбутнього вчителя початкових класів до особистісно орієнтованого навчання молодших школярів: автореф. дис. на здобуття наук. ступеня канд. пед. наук : спец. 13.00 .04 «Теорія і методика професійної освіти». Х., 2007. 20 с.

[12] Шкуратяна Н. Сучасна українська літературна мова. Модульний курс : навч. посіб. / Н. Шкуратяна, С. Шевчук. К. : Вища шк., 2007. 823 с.

[13] Ющук І. Вступ до мовознавства : навч. посіб. К. : Рута, 2000. 128 с.

[14] Яковенко О. А. Використання досвіду народознавства в сучасній освіті. Вісник Житомирського державного університету. 2010. Вип. 52. С. $130-133$

\section{REFERENCES (TRANSLATED AND TRANSLITERATED)}

[1] Boghush A. M. Lysenko N. V. Ukrajinsjke narodoznavstvo v doshkiljnomu zakladi (Ukrainian ethnography in preschool). Praktyku: navch. posib. K. : Vyshha shk., 2003. 206 s. (in Ukrainian)

[2] Bodalev A. Psykhologhyja novoj эry : kompetentnosty yly bespomoshhnostj (The psychology of a new era: competence or helplessness). URL: http://psy.I September.Ru/2001/47/45.htm. (in Russian)

[3] Ghoncharenko S. U. Ukrajinsjkyj pedaghoghichnyj slovnyk (Ukrainian Pedagogical Dictionary). K. : Lybidj, 1997.376 s. (in Ukrainian)

[4] Encyklopedija ukrajinoznavstva dlja shkoljariv i studentiv (Encyclopedia of Ukrainian Studies for Schoolchildren and Students) / avt.-uklad. V. V. Olifirenko, T. V. Olifirenko, L. V. Olifirenko. D. : Stalker, 1999. 496 s. (in Ukrainian)

[5] Kraevsjkyj V. Predmetnoe y obshhepredmetnoe $v$ obrazovateljnkh standartaykh (Subject and general subject in educational standards). Pedaghoghika. 2003. № 3. S. 3-10. (in Russian)

[6] Koncepcija movnoji osvity 12-richnoji shkoly (Concept of language education 12-year school). Dyvoslovo. 2002. № 8. S. 58-62. (in Ukrainian)

[7] Novyj tlumachnyj slovnyk ukrajinsjkoji movy : u 4 t. (New Explanatory Dictionary of the Ukrainian language) / uklad. V. Jaremenko,

O. P. Slipushko. K. : Akonit, 1999. T. II. S. 305. (in Ukrainian)

[8] Popova T. Formuvannja socialjnoji kompetentnosti uchniv (Formation of social competence of students). Pedaghoghichna skarbnycja Donechchyny. 2004. № 2 (20). S. 42-43. (in Ukrainian)

[9] Praktycheskyj yntellekt (Practical intelligence) / pod. obshh. red. R. Stenbergha. SPb. : Pyter, 2002. 272 s. (in Russian)

[10] Raven Dzh. Pedaghoghycheskoe testyrovanye: Problemy, zabluzhdenyja, perspektyvy (Pedagogical Testing: Problems, Misconceptions, Perspectives) / Dzh. Raven ; per. s anghl. M. : Koghyto-Centr,1999. 144 s. (in Russian)

[11] Shapoval Ju. Pedaghoghichni umovy formuvannja ghotovnosti majbutnjogho vchytelja pochatkovykh klasiv do osobystisno orijentovanogho navchannja molodshykh shkoljariv (Pedagogical conditions of forming the readiness of the future teacher of elementary school for the personally oriented education of junior pupils): avtoref. dys. na zdobuttja nauk. stupenja kand. ped. nauk: spec. 13.00 .04 «Teorija i metodyka profesijnoji osvity». Kh., 2007. 20 s. (in Ukrainian)

[12] Shkuratjana N. Suchasna ukrajinsjka literaturna mova. Moduljnyj kurs (Contemporary Ukrainian Literary Language. Modular course): navch. posib. / N. Shkuratjana, S. Shevchuk. K. : Vyshha shk., 2007. 823 s. (in Ukrainian)

[13] Jushhuk I. Vstup do movoznavstva (Introduction to linguistics): navch. posib. K. : Ruta, 2000. $128 \mathrm{~s}$. (in Ukrainian)

[14] Jakovenko O. A. Vykorystannja dosvidu narodoznavstva $v$ suchasnij osviti (Using the experience of ethnography in modern education). Visnyk Zhytomyrsjkogho derzhavnogho universytetu. 2010. Vyp. 52. S. 130-133. (in Ukrainian) 